International Journal of Advanced Biological and Biomedical Research Available online at http:www.ijabbr.com

Volume 8, Issue 1 (2020) pp. 86-91

DOI: 10.33945/SAMI/IJABBR.2020.1.9

Original Article

\title{
Evaluation of Two Types of Vitamin D Receptor Gene Morphism in Patients with Type 2 Diabetes and Obesity
}

\author{
Sahar Azizi*, Roudabe Behzadi Andouhjerdi, Hamidreza Mohajerani
}

Departmant of genetic, Islamic Azad University of Center Tehran Branch, Tehran, Iran

*Corresponding Author E-mail: beh.abdoli@aut.ac.ir

Received: 1 June 2019, Revised: 18 August 2019, Accepted: 3 September 2019

\begin{abstract}
Background: Diabetes is the most common endocrine disorder that affects many people each year. Many people suffer from diabetes and obesity. The effects of renoprotective vitamin $\mathrm{D}$ and its analogues in chronic kidney diseases, including diabetic nephropathy, have been reported. The aim of this study was to investigate the rs731236 and rs2228570 polymorphisms of vitamin D receptor gene (GDR) in patients with type 2 diabetes and obesity.

Methods: In this case-control study, 120 patients with type 2 diabetes and 120 healthy controls (control group) referred to Amiralmomenin Arak Hospital were investigated during 2018. After collecting clinical data and performing laboratory tests, DNA samples were extracted from blood samples by phenol chloroform method, and polymorphisms in specimens were examined by specific genotypes. Data were analyzed by SPSS 22 software.

Results: There was no correlation between Taq1 and Fok1 polymorphisms with both healthy and healthy patients. Although the frequency of CT genotype was higher in both groups, this difference was not significant (P-value $>0.05$ ).

Conclusions: No evidence was found that VDR gene polymorphisms play a role in the risk of type 2 diabetes and obesity in Iranian subjects. Further studies in prospective cohort studies should be performed to determine the genome-wide association to evaluate the direct effect of these polymorphisms on type 2 diabetes.
\end{abstract}

Key words: Type 2 diabetes, Diabetes, Obesity, Vitamin D receptor gene (VDR), Genotype, Polymorphism

\section{Introduction}

The prevalence of diabetes is increasing worldwide, in 2010, about 200 million people are diabetic, and according to the World Health Organization (WHO), it is expected to reach about 300 million in 2025 (Arababadi et al., 2012). The pathology of this disease is complex, so both environmental and genetic factors may play a role in this matter. Todays, several genes have been identified in relation to type 2 diabetes. Genetic determinants interact with environmental factors to create the final phenotype of disease (Hamman, 1992). Obesity is one of the most important causes of type 2 diabetes; although the final interaction of genes with environmental factors, including nutrition 
and obesity, may be related to different gene variants. Therefore, identifying varieties of a gene not only improves the understanding of the pathophysiology of the disease but may also reveal biochemical and physiological pathways that bind different risk factors and create the potential for disease.

Based on epidemiological studies, it has been suggested that vitamin D deficiency may be a risk factor for glucose intolerance and also a risk to insulin resistance (Reis et al., 2005), metabolic syndrome (Martini and Wood, 2006) and diabetes progression (Reis et al., 2005).

The function of vitamin $\mathrm{D}$ is mediated through the vitamin $\mathrm{D}$ receptor, the gene that encodes the VDR is found on the chromosome 12 cen-q12 and several polymorphisms in the gene have been identified including TaqI, FokI, BsmI, ApaI (Bid et al., 2009; Uitterlinden et al., 2004). Recent studies have reported that single-nucleotide polymorphisms within the VDR gene may affect the stability, quantity, and activity of the VDR protein as well as the speed of the transcription of the VDR gene (Palomer et al., 2008). Genetic society studies have reported association between VDR gene polymorphisms with type 2 diabetes and obesity (Reis et al., 2005). It also observed that variants of the VDR gene may have the same effect in different racial groups (Kittles and Weiss, 2003). But one of the most important determinants of the success of nutrition policies at the population level is the awareness of the prevalence of "Responsive genotypes" and the identification of those who are at risk for vitamin D deficiency.

Therefore, this study was aimed to investigate the interaction of vitamin $\mathrm{D}$ receptor gene polymorphisms with type 2 diabetes and obesity for the prevention and treatment of these individuals.

\section{Materials and methods}

In this case-control study, 120 patients with type 2 diabetes and 120 healthy controls (control group) $\mathrm{n}$ the age range of 38 to 80 years referred to Amiralmomenin Hospital in Arak, Iran were investigated during 2018.

Written informed consent was taken from all study participants and the study was approved by the Ethics Committee of faculty of Basic Sciences Dissertation of biology Islamic Azad University Central Tehran Branch.

Participants information was collected using a questionnaire including age, gender, body mass index (BMI) and medical history. Entry requirements included the absence of a medical condition or medical disorder requiring drug intervention, a history of chronic diseases, especially coronary artery disease, nephropathy, thyroid disease, and the last stage of renal or liver disease (ESRD, ESLD), non-pregnancy, and lactation.

\section{Laboratory tests}

$5 \mathrm{~mL}$ of blood was taken from each patient after 12 hours of fasting, Blood samples were centrifuged; Samples were stored with the anticoagulant ethylene diamine tetra-acetic acid and were stored until use at $4{ }^{\circ} \mathrm{C}$. Blood samples were collected in EDTA-containing tubes and DNA samples from the whole blood were extracted by a DNA extraction kit of the brand PrimePrepth (Genet BIO, South Korea) according to the details given in the kit for the separation of the genomic DNA. DNA was stored at $-20{ }^{\circ} \mathrm{C}$ until polymorphisms were determined (Shab-Bidar et al., 2011). 


\section{Determination of polymorphisms}

The genotype was determined at the locations of single nucleotide VDR gene polymorphisms by the PCR-RFLP method by means of heat transfer device (Corbett Research, Gradient Palm cycler, Australia) and enzymatic digestion of the products by restriction enzymes (Fementas, Thermo Scientific, Canada). To perform RFLP on the PCR product, exposed the PCR product with the restriction enzyme, and maintained for $16 \mathrm{~h}$ at $37^{\circ} \mathrm{C}$. Along with the specimens, two specimens were controlled: A sample without enzyme (Positive control) and one sample without DNA (Negative control). After the required time, PCR products were analyzed by electrophoresis on a $1.5 \%$ agarose containing ethidium bromide gel and detected by gel recording and imaging apparatus gel (documentation system UVItec; UVIdoc, England).

FokI Polymorphism (rs10735810): This polymorphism was amplified by PCR using back (5'-CCCTTCATGGAAACACCTTGCTTC-3') and forth (5'-AGCTGGCCCTGGCACTGACT-3') primers according to (Deng et al., 2002). And 273 bp products resulted. PCR was performed in 30 cycles at $58{ }^{\circ} \mathrm{C}$. DNA was digested by the FokI restriction enzyme. Genotypes of the beginning codon of polymorphism FokI of the vitamin D receptor were CC, CT, and TT.

TaqI Polymorphism (rs731236): This polymorphism was amplified by PCR using back (5'-TCATGGCTGAGGTCTCAAGGG-3') and forth (5'-CAGAGCATGGACAGGGAGCAA-3') primers according to (Deng et al., 2002). And 737 bp products resulted. PCR was performed in 30 cycles at $64^{\circ} \mathrm{C}$. DNA was digested by the TaqI restriction enzyme. Genotypes of the beginning codon of polymorphism TaqI of the vitamin D receptor were CC, CT, and TT.

\section{Statistical calculations}

SPSS 22 software were used to the analysis of the characteristics of the participants and the calculation of the frequency of genotypic and allelic polymorphisms, as well as the evaluation of the relationship between different genotypes and bone density, and other statistical analyzes. Differences in the distribution of alleles and genotypes as well as in order to determine the deviation from Hardy Weinberg equilibrium were used in both healthy and healthy groups Chi square test. The relationship between different polymorphism genotypes with bone density was also analyzed by ANOVA. Charts related to these analyzes are drawn by Microsoft Excel software.

\section{Results}

$49.6 \%$ (119 people) of the 240 patients examined was female and $50.4 \%$ (121 people) was male. $11.3 \%$ of people were aged 36 to 45 years old and $88.8 \%$ was older than 46 years old. The demographic data of the subjects examined is shown in Table 1.

Table1. Comparison of characteristics of T2D and control groups

\begin{tabular}{cccc}
\hline & T2D $(\mathrm{n}=120)$ & control $(\mathrm{n}=120)$ & Min-Max \\
\hline Age & $60.55 \pm 10.46$ & $60.27 \pm 10.52$ & $38-80$ \\
Height & $169.50 \pm 11.44$ & $171.05 \pm 11.14$ & $141-193$ \\
Weight & $74.53 \pm 12.52$ & $76.27 \pm 12.36$ & $51-105$ \\
\hline
\end{tabular}


According to Table 2, no association was found between the frequency of genotypes and T and $\mathrm{C}$ alleles with type 2 diabetes in the studied population. It is clear that the level of significance is more than 0.05 and therefore it is concluded that there is no significant relationship between polymorphisms rs2228570 and rs731236 with the probability of diabetes type 2 and obesity.

Table 2. The results of polymorphisms TaqI and FokI

\begin{tabular}{ccccc}
\hline & CC & CT & TT & P-Value \\
\hline TaqI & & & & 0.807 \\
T2D & $20(16.7 \%)$ & $54(45 \%)$ & $46(38.3 \%)$ & \\
Control & $19(15.8 \%)$ & $59(49.2 \%)$ & $42(35 \%)$ & \\
FokI & & & & 0.607 \\
T2D & $2(1.7 \%)$ & $70(58.3 \%)$ & $48(40 \%)$ & \\
Control & $4(3.3 \%)$ & $71(59.2 \%)$ & $45(37.5 \%)$ & \\
\hline
\end{tabular}

\section{Discussion}

In this study, the association of this polymorphism with type 2 diabetes and obesity were investigated. There was no significant difference in frequency of them in comparison with subjects in both groups.

The findings of some different studies suggest that there is a link between genotype and haplotypes of VDR polymorphism in people with type 1 diabetes (Turpeinen et al., 2003). While our study has shown contradictory results in various relationships between the genetic variants of VDR and type 2 diabetes. In previous studies, the results of different Taq1 genotypes in the diabetic group with the control group showed a higher prevalence of $\mathrm{tt}$ and $\mathrm{Tt}$ in the diabetic population (Nosratabadi et al., 2011). On the other hand, Bid et al., demonstrated using Fok1, Bsm1, and Taq1 polymorphisms that there was no relationship between VDR polymorphisms and type 2 diabetes (Bid et al., 2009). Also, other studies in Turkey and Spain failed to demonstrate this connection (Valdivielso and Fernandez, 2006; Dilmec et al., 2011).

Based on our findings, there was no correlation between the frequency of genotypes and $\mathrm{T}$ and $\mathrm{C}$ alleles with type 2 diabetes in the studied population.

According to a study by Ramos-Lopez et al., some haplotypes can be considered as protective against the susceptibility to type 1 diabetes in the German population, and the cause of the protection of these rare haplotypes is currently unclear, may also be related to the metabolism of vitamin D in the body (Ramos-Lopez et al., 2006).

VDR gene polymorphisms in type 2 diabetic patients in the Polish population were also investigated, No association was found between the genotype frequency and allele and haplotype of the three BsmI/ApaI/TaqI polymorphisms (Malecki et al., 2003). In the study of the relationship between vitamin $\mathrm{D}$ receptor gene polymorphism (ApaI/FokI) and micro/macrovascular complications in postmenopausal women with type 2 diabetes in Brazil, there was no significant difference in the allele frequency and genotype of two polymorphisms (Maia et al., 2016).

In our study, there was no significant correlation between polymorphisms FokI with the probability of diabetes mellitus type 2 and obesity. There was also no correlation between the frequency of genotypes and $\mathrm{T}$ and $\mathrm{C}$ alleles with type 2 diabetes in the studied population. There was also no correlation between the frequency of genotypes and $\mathrm{T}$ and $\mathrm{C}$ alleles with 
type 2 diabetes in the studied population. In contrast, the population of Saudi Arabia, FokI polymorphism was associated with increased risk of T2D (Al-Daghri et al., 2014).

The reasons for the difference between the results of the study can be explained by the genetic differences in the population studied as well as the environmental factors (Simmons, 2007; Carey et al., 2009).

Taq1 and Fok1 polymorphisms have been reported to be the best and most suitable model for expression of the VDR gene mRNA.

Since there are sporadic studies with different outcomes, future studies can be done with more sample numbers and suspicious haplotypes. Also, the amount and level of 1-25 hydroxyvitamin D3 levels are not available for samples, measuring the level of vitamin D3 and its relationship with VDR haplotypes can also be an advantage in future studies.

\section{Acknowledgments}

Thanks to the advice, guidance and efforts of the Research and Development Research Unit of Amiralmomenin Hospital and Islamic Azad University of Arak.

\section{References}

Al-Daghri, NM, Al-Attas, OS, Alkharfy, KM, Khan, N, Mohammed, AK, Vinodson, B, Ansari, MG, Alenad, A, Alokail, MS. (2014). Association of VDR-gene variants with factors related to the metabolic syndrome, type 2 diabetes and vitamin D deficiency, Gene., 542(2):129-133.

Arababadi, MK, Reza Mirzaei, M, Ali Sajadi, SM, Hassanshahi, G, Ahmadabadi, BN, Salehabadi, VA, Derakhshan, R, Kennedy, D. (2012). Interleukin (IL)-10 gene polymorphisms are associated with type 2 diabetes with and without nephropathy: a study of patients from the southeast region of Iran, Inflammation., 35(3):797-802.

Bid, HK, Konwar, R, Aggarwal, CG, Gautam, S, Saxena, M, Nayak, VL, Banerjee, M. (2009). Vitamin D receptor (FokI, BsmI and TaqI) gene polymorphisms and type 2 diabetes mellitus: a North Indian study, Indian J. Med. Sci., 63(5):187-194.

Carey, WB, Crocker, AC, Elias, ER, Feldman, HM, Coleman, WL. (2009). DevelopmentalBehavioral Pediatrics E-Book. Elsevier Health Sciences.

Deng, HW, Shen, H, Xu, FH, Deng, HY, Conway, T, Zhang, HT, Recker, RR. (2002). Tests of linkage and/or association of genes for vitamin $\mathrm{D}$ receptor, osteocalcin, and parathyroid hormone with bone mineral density, J. Bone. Miner. Res., 17(4):678-686.

Dilmec, F, Uzer, E, Akkafa, F, Kose, E, van Kuilenburg, AB. (2010). Detection of VDR gene ApaI and TaqI polymorphisms in patients with type 2 diabetes mellitus using PCR-RFLP method in a Turkish population, J. Diabetes Complicat., 24(3):186-191.

Hamman, RF. (1992). Genetic and environmental determinants of non-insulin-dependent. diabetes mellitus (NIDDM), Diabetes Metab. Rev., 8(4):287-338.

Kittles, RA, Weiss, KM. (2003). Race, ancestry, and genes: implications for defining disease risk, Annu. Rev. Genomics Hum. Genet., 4(1):33-67. 
Maia, J, da Silva, AS, do Carmo, RF, de Mendonça, TF, Griz, LH, Moura, P, Bandeira, F. (2016). The association between vitamin D receptor gene polymorphisms (TaqI and FokI), Type 2 diabetes, and micro-/macrovascular complications in postmenopausal women, Appl. Clin. Genet., 9:131136.

Malecki, MT, Frey, J, Moczulski, D, Klupa, T, Kozek, E, Sieradzki, J. (2003). Vitamin D receptor gene polymorphisms and association with type 2 diabetes mellitus in a Polish population, Exp. Clin. Endocrinol. Diabetes., 111(8):505-509.

Martini, LA, Wood, RJ. (2006). Vitamin D status and the metabolic syndrome, Nutr Rev., 64(11):479-486.

Nosratabadi, R, Arababadi, MK, Salehabad, VA. (2011). Vitamin D receptor polymorphisms in type 2 diabetes in southeastern Iranian patients, Laboratory Med., 42(1):32-34.

Palomer, X, González-Clemente, JM, Blanco-Vaca, F, Mauricio, D. (2008). Role of vitamin D in the pathogenesis of type 2 diabetes mellitus, Diabetes Obes. Metab., 10(3):185-197.

Ramos-Lopez, E, Jansen, T, Ivaskevicius, V, Kahles, H, Klepzig, C, Oldenburg, J, Badenhoop, K. (2006). Protection from type 1 diabetes by vitamin D receptor haplotypes, Ann. N. Y. Acad. Sci., 1079(1):327-334.

Reis, AF, Hauache, OM, Velho, G. (2005). Vitamin D endocrine system and the genetic susceptibility to diabetes, obesity and vascular disease. A review of evidence, Diabetes Metab., 31(4):318-325.

Shab-Bidar, S, Neyestani, TR, Djazayery, A. (2011). Efficacy of vitamin D3-fortified-yogurt drink on anthropometric, metabolic, inflammatory and oxidative stress biomarkers according to vitamin $\mathrm{D}$ receptor gene polymorphisms in type 2 diabetic patients: a study protocol for a randomized controlled clinical trial, BMCEndocr. Disord., 11(1):12.

Simmons RA. (2007). Role of metabolic programming in the pathogenesis of $\beta$-cell failure in postnatal life, Rev. Endocr. Metab. Disord., 8(2):95-104.

Turpeinen, H, Hermann, R, Vaara, S, Laine, AP, Simell, O, Knip, M, Veijola, R, Ilonen, J. (2003). Vitamin D receptor polymorphisms: no association with type 1 diabetes in the Finnish population, Eur. J. Endocrinol., 149(6):591-596.

Uitterlinden, AG, Fang, Y, Van Meurs, JB, Pols, HA, Van Leeuwen, JP. (2004). Genetics and biology of vitamin D receptor polymorphisms, Gene., 338(2):143-156.

Valdivielso, JM, Fernandez, E. (2006). Vitamin D receptor polymorphisms and diseases, Clin. Chim. Acta., 371(1-2):1-12.

How to cite this article: Sahar Azizi, Rodabe Behzadi Andohjerdi, Hamidreza Mohajerani, Evaluation of Two Types of Vitamin D Receptor Gene Morphism in Patients with Type 2 Diabetes and Obesity. International Journal of Advanced Biological and Biomedical Research, 2020, 8(1), 86-91. Link: http://www.ijabbr.com/article 36317.html 